\title{
doispontos:
}

\section{Três corpos: Artaud, Foucault, Deleuze ${ }^{1}$}

\author{
Diogo Sardinha \\ Centro de Filosofia das Ciências, Universidade de Lisboa, Lisboa, Portugal. \\ diogo_pt@hotmail.com
}

Resumo: O texto pretende analisar o itinerário realizado por Foucault em torno da noção de corpo, levando em consideração duas tripartições: uma interna à obra de Foucault, considerando as três etapas de seu pensamento, a saber, epistemológica, política e ética, e uma segunda, externa à obra de Foucault, que visa uma leitura comparada entre Deleuze e Foucault, a partir da leitura que ambos fazem de Artaud. Esse contraste permite trazer à luz uma rede de tensões, cumplicidades, mudanças e distanciamentos entre Foucault e Deleuze.

Palavras-Chave: corpo; poder; saber; ética; literatura.

Abstract: The text intends to analyze the itinerary realized by Foucault around the notion of the body, taking into account two triple divisions: one internal to the work of Foucault, taking into consideration the three stages of his thought, namely, the epistemological, the political and the ethical, and a second one, external to Foucault's work, which aims at a comparative reading of Deleuze and Foucault, taking as its reference-point their own readings of Artaud. This contrast allows us to bring to light a network of tensions, complicities, changes and estrangements between Foucault and Deleuze.

Key-words: body; power; knowledge; ethics; literature.

Por comodidade da exposição, o trabalho de Foucault será abordado aqui a partir da distinção entre três polos temáticos, que correspondem a outros tantos momentos de sua produção. O primeiro polo é simultaneamente epistemológico e literário e marca de forma visível os escritos da primeira metade dos anos 1960, manifestando-se de forma imediata na História da loucura na idade clássica, de 1961, bem como em textos inspirados da literatura. O segundo polo é mais diretamente político e se torna notório durante a década de 1970, com duas obras maiores que são Vigiar e punir, de 1975, e A Vontade de saber, de 1976. Por fim, um terceiro polo, que designaremos como ético, concentra diversos estudos da primeira metade dos anos 1980, culminando com O Uso dos prazeres e O Cuidado de si, livros de 1984. Feita esta diferenciação, é preciso introduzir de imediato duas ressalvas, que apesar de previsíveis são todavia necessárias. Por um lado, a indicação destes três núcleos de tratamento do corpo e dos corpos não esgota, de forma alguma, o discurso de Foucault sobre o assunto, havendo múltiplos textos que lidam com o mesmo tema para lá dos mencionados. Por outro lado, nenhum destes polos é exclusivo de elementos típicos de outros polos; ou seja, sabemos que há considerações políticas tanto no âmbito epistemológico quanto no ético, assim como podem existir conteúdos epistemológicos no domínio da ética e da política, e por aí vai, o importante sendo de conceber Foucault não tanto como um pensador que em cada período de sua produção apenas se consagra a um domínio (apesar de ele também o ter feito, por exemplo nas Palavras e as coisas, que se situam num âmbito do saber, sem qualquer contato com o que mais tarde ele chamará de poder), quanto como um pensador que permite passagens e permeabilidades entre os campos científico, político, literário, 
plástico, filosófico e outros. Nos instalamos, então, num equilíbrio entre dois pratos da balança, de um lado a consideração de três polos maiores, o que como veremos nos facilitará uma certa harmonia na análise; e de outro, a memória de que estes centros não esgotam a riqueza e diversidade de contributos de Foucault para um pensamento do corpo.

Partirei assim desta tripartição e examinarei o percurso que conduz de cada polo aos outros, tomando como guia uma personalidade literária cuja influência, sobre Foucault e seus contemporâneos franceses, foi notória, personalidade que aparece como sendo de grande pertinência para o tratamento do corpo: se trata do poeta, escritor, ator, teórico do teatro, dramaturgo e artista plástico Antonin Artaud, que viveu durante a primeira metade do século XX (1896-1948). Se fosse preciso apresentar de início duas razões para evocá-lo, uma seria o fato que Foucault se serve do que Artaud escreve acerca do corpo, a fim de teorizar filosoficamente o suplício do sujeito, como veremos adiante; e outra, o fato de que Deleuze se inspira também de Artaud, no intuito de teorizar o corpo sem órgãos, expressão de Artaud aliás, criador constante e intimamente preocupado com o corpo em seus mais diversos estados e manifestações. Além do mais, a referência a Artaud traz consigo uma vantagem adicional: visto que Foucault e Deleuze se inspiram dele de forma diversa, veremos por intermédio do primeiro o quanto os dois últimos se distanciam um do outro ao longo dos anos, o tema do corpo aparecendo desse jeito como um catalisador para melhor captar as singularidades de Foucault e de Deleuze. Por tudo isso, Artaud, Foucault e Deleuze constituem a segunda tripartição sobre a qual me apoiarei para explorar o itinerário foucaultiano concernente ao corpo.

A partir de aqui, as etapas que me proponho percorrer são as seguintes. Num primeiro estádio tentarei mostrar o que Foucault diz do corpo, com referência a Artaud, durante o período epistemológico. Num segundo momento, atentarei no que dele diz a partir do polo político. Num terceiro momento, enfim, me concentrarei na ética foucaultiana, simultaneamente atentando em Deleuze, que aparecerá então em grande contraste em relação à Foucault.

O primeiro escrito que evocarei não causará surpresas: se trata da História da loucura, que retoma a afinidade, sugerida primeiramente por Artaud em sua "Carta sobre Lautréamont", de 1946 (ARTAUD, 1974, t. XIV, vol. 1, p. 32-37), entre ele mesmo, Nerval, Van Gogh e Nietzsche, que Foucault apresenta como autores dessas "obras de loucura" (FOUCAULT, 1961, p. 663) que mudaram nossa maneira de ver a arte e o mundo. Aqui, o tema da loucura é cardinal, e é verdade que Artaud foi condenado a vários anos de reclusão em asilo psiquiátrico, como Foucault recorda: "Antonin Artaud era esquizofrênico: foi ele quem, após o enfraquecimento do surrealismo, criou uma via no mundo poético abrindo novas perspectivas" (FOUCAULT, 1994, p. 132). O escritor lhe interessa desde logo pela estranha proximidade que nele se estabelece entre a loucura e a arte, pois Foucault sabe que condenar como loucos aqueles para quem a escrita é um lugar privilegiado de experimentação e ruptura radical, equivale a desprezar e abafar a própria criação. Além disso, Artaud se chamou por vezes de louco, por exemplo em Artaud le Mômo, de 1947: "EU/ visado em minha loucura” (ARTAUD, 1974, t. XII, p. 18). ${ }^{2}$ Ele aceita então sua própria loucura, porém apenas numa estratégia para voltá-la, sem tardar, contra aqueles que o julgam, astúcia por intermédio da qual ele se transforma no primeiro acusador dos médicos e psiquiatras, verdadeiros responsáveis pela existência da loucura. Assim, lemos nos fragmentos reunidos no "Dossiê de Artaud le Mômo": "Digo que a loucura é uma artimanha/ e que sem a medicina ela não teria existido” (ARTAUD, 1974, t. XII, p. 214). Duas páginas adiante, lemos ainda o seguinte: "Os médicos de asilos de alienados são sádicos conscientes e premeditados,/ e aquele que me disser: Antonin Artaud, és louco / lhe responderei: Tu és o cínico, e bem te conheço/ Se não tivesse havido médicos não teria havido doentes/ pois foi pelos médicos e não pelos doentes que a sociedade começou" (ARTAUD, 1974, t. XII, p. 216). Esta inversão teve, com certeza, com que seduzir Foucault, para o qual a loucura apenas existe em sociedade. Mas que importância tem isso para o tratamento do nosso problema? É 
que o ataque contra a medicina e a reivindicação da loucura são dois passos que precedem um novo discurso sobre o corpo, no qual este é apresentado não como um dado natural, antes como o resultado de convenções e, por conseguinte, apto a ser transformado. Abordemos este aspecto com algum pormenor.

No "Dossiê de Artaud le Mômo" encontramos o seguinte passo: "Os médicos são os inimigos-natos do delírio/ atribuição de uma realidade e de um ser a algo que não existia/ quando o delírio,/ quer dizer a imaginação reivindicadora,/ é a regra da realidade” (ARTAUD, 1974, t. XII, p. 218). Uma vertente do discurso de Artaud sobre o corpo humano decorre desta concepção da imaginação como sendo "delirante", num sentido antimédico - imaginação que é livre porque ultrapassa os limites do espaço de funcionamento razoável que supostamente lhe estaria atribuído. Podemos desenvolver esta ideia buscando inspiração numa afirmação de Artaud, extraída de outro livro, O Teatro e seu duplo, de 1938, segundo a qual "é preciso admitir que tudo na destinação de um objeto, no sentido ou na utilização de uma forma natural, tudo é questão de convenção” (ARTAUD, 1974, t. IV, p. 52). Artaud dá um exemplo concreto, imediatamente relacionado com o nosso tema: "Entende-se que uma mulher bonita tem uma voz harmoniosa; se desde que o mundo é mundo tivéssemos ouvido todas as mulheres lindas nos chamar com toques de trompa e nos cumprimentar com barridos, por toda a eternidade teríamos associado a ideia do barrido à ideia de mulher bonita, e com isso parte de nossa visão interior do mundo teria sido radicalmente transformada" (ARTAUD, 1974, t. IV, p. 52). Tal como a voz e a trompa no caso da mulher bonita, cada objeto cumpre uma função ou tem uma finalidade, associada por uma parte ao sentido que lhe é atribuído (ao objeto); e, por outra parte, à constituição do mundo no interior do qual esse objeto desempenha o seu papel. A transformação do objeto induz, por conseguinte, uma metamorfose tanto de seu sentido próprio, quanto do quadro geral no qual ele se inscreve. Estes argumentos, expostos por Artaud em O Teatro e o seu duplo, visam propor como tarefa maior do teatro a de mudar radicalmente os usos dos objetos, no intuito de mostrar quão convencionais são aqueles que habitualmente lhes são conferidos. Para isso, sugere Artaud, o teatro poderia inspirar-se da peste, momento de derrocada da ordem, e da substituição (ainda que provisória ou até efémera) das convenções de sentido e de valor, em uma palavra, das convenções acerca da finalidade de um ser. Como sugerirá Deleuze anos mais tarde em Crítica e clínica, de 1993: "Entre o teatro e a peste, Artaud cria um símbolo no qual cada uma das forças duplica e relança a outra” (DELEUZE, 1997, 152). A fugacidade de uma nova associação, ocasionada pelo teatro tanto quanto pela poesia, compensa toda associação convencional, cujo caráter contingente se revela plenamente nesse mesmo instante. A nova associação, assim estabelecida, mostra que as coisas poderiam ser de outro jeito; e que este fato é mais verdadeiro do que o fato de que as coisas se apresentam habitualmente de uma certa forma. Dez anos mais tarde, Artaud radicaliza sua própria ideia com respeito ao corpo, não mais recorrendo ao caso da mulher bonita e de sua voz, mas ao do ser humano em geral: é a invenção daquilo a que chamará de corpo sem órgãos; reivindicação delirante por excelência de uma metamorfose do humano, no sentido da palavra "delírio" evocado atrás, isto é, que diz respeito a uma imaginação não-convencional, a qual escapa às convenções da razão, incluindo as da razão médica. Eis o que lemos em um de seus textos tardios, Para acabar de vez com o juízo de deus, de 1948: "Ora, agora é preciso emascular o homem. [... ]/ - Colocando-o de novo, pela última vez, na mesa de autópsia para refazer sua anatomia./ [...] O homem está doente porque está mal construído./ Temos que nos decidir a desnudá-lo para raspar esse animalejo que mortalmente o corrói,/ deus,/ e juntamente com deus/ os seus órgãos. / Pois metam-me se quiserem numa camisa de forças,/ mas não há nada mais inútil que um órgão./ Quando lhe tiverem feito um corpo sem órgãos/ então o terão desembaraçado de todos seus automatismos e devolvido a sua verdadeira liberdade./ Então vocês vão ensiná-lo de novo a dançar às avessas / como no delírio dos bailes populares/ e este avesso será seu verdadeiro direito" (ARTAUD, 1974, t. XIII, p. 104). Este avesso do humano aparece, assim, como uma ordem mais verídica, emancipada dos automatismos. Com a parte final da citação, compreendemos melhor a coerência que existe entre o projeto anorgânico de Artaud e a maneira como este põe em causa 
as convenções, pois lemos nessa parte de frase que a evidência do habitual é o que cria impedimentos à liberdade de pensar. Temos de captar esta ideia em toda a sua profundidade, porque ela é bem mais do que uma simples crítica da opinião: ela atinge o coração da ciência, a qual estabelece o que é um órgão, para que serve e por quê não se pode prescindir dele. Ora, são estas evidências que é necessário destruir poética e teatralmente, isto é artisticamente. Em simultâneo, vemos como a escrita de Artaud pode ser comparada com a de Nietzsche, desde logo quando este atribui à arte a função de um remédio contra o conhecimento e o empobrecimento da vida (NIETZSCHE, 1886, \$5). Ambos os autores compreendem a arte como sendo mais verdadeira do que a ciência, não somente no final, isto é, nos resultados a que chega cada uma; mas desde o início, no desmantelamento - que a arte empreende - dos automatismos ou das regularidades dos objetos, dos quais a razão pretenderia formular as leis. $\mathrm{O}$ avesso dos objetos e dos corpos, tudo aquilo de que são capazes mais além das convenções, eis um espaço para sua própria libertação, ou para a revelação do que estes objetos e corpos podem ser, para lá do que é costume serem. Associando ao tema da loucura o tema do corpo, das dores físicas e existenciais decorrentes do fato de o humano estar doente por estar mal construído, mas também das potencialidades e recursos deste corpo, Foucault pode enfim referir Artaud como um símbolo do "pensamento do fora", que concerne um novo lugar descoberto pela literatura, lugar exterior de uma materialidade que se opõe à interioridade da consciência; um "fora" que Foucault reconhece "em Artaud, quando toda a linguagem discursiva é instada a se soltar na violência do corpo e do grito, e o pensamento, deixando a interioridade falaz da consciência, se torna energia material, sofrimento da carne, perseguição e dilaceramento do próprio sujeito" (FOUCAULT, apud TERNES, 2011, p. 139). Porém, após ter admirado tanto os escritos e a experiência de Artaud, Foucault não falará mais dele a partir do final dos anos 1960. Podemos apresentar a publicação de Vigiar e punir como momento que consagra definitivamente seu afastamento do poeta. Vejamos porquê.

Para melhor situar a posição de Foucault sobre o corpo no domínio político, note-se o que ele escreve, desde as primeiras páginas do livro sobre a prisão, a respeito daquilo a que chama "a 'alma' moderna", que considera o ponto de apoio para o exercício de um certo poder punitivo. A transformação do regime penal nas últimas décadas do século XVIII põe termo ao regime dos suplícios. Doravante, em vez de submeter os condenados a castigos físicos cruéis, a justiça punirá antes de mais pelo aprisionamento; em vez de supliciar o corpo, ela desejará corrigir a alma. Ao mesmo tempo desenvolve-se um conjunto diverso de técnicas de vigilância e domesticação dos corpos individuais, empregues no exército, na escola, na oficina, no hospital, na administração da cidade. De tal maneira que a punição da alma, compreendida como princípio dos bons e maus comportamentos, é acompanhada por uma produção de individualidade, resultante da aplicação dos procedimentos de hierarquização, de gestão do tempo e do espaço, de exame dos saberes e condutas, numa palavra, de tudo aquilo que Vigiar e punir chama: o exercício de uma tecnologia de poder. Esta tecnologia só pode constituir as almas individuais sob condição de tomar como alvo, porém de modo inteiramente novo, os corpos. Quer isto dizer que as almas são menos reais do que os corpos? Foucault responde: "Não se deveria dizer que a alma é uma ilusão, ou um efeito ideológico, mas afirmar que ela existe, que tem uma realidade, que é produzida permanentemente, em torno, na superfície, no interior do corpo pelo funcionamento de um poder exercido sobre os que são punidos" (FOUCAULT, 1999, p. 28). Assim, a alma é real, conquanto seja um produto. Num trecho conexo, Foucault qualifica a realidade dela como "histórica", ao mesmo tempo que lhe retira de uma vez por todas o estatuto de entidade primeira: "Esta alma real, e incorpórea, não é em nada substância; é o elemento onde se articulam os efeitos de um certo tipo de poder e a referência de um saber" (FOUCAULT, 1999, p. 28). Compreendemos por isso que Foucault a escreva entre aspas: estas indicam que não se trata da alma-princípio-de-vida nem da alma imortal, mas sim daquela de que cada indivíduo é dotado pelos mecanismos em funcionamento numa sociedade, e que desenvolvem nele automatismos de conduta e de pensamento. A generalização das disciplinas ao longo do século XVIII produziu uma alma moderna geral e individual. Geral, na medida em que por ela todos os indivíduos são 
iguais na sua humanidade e, por conseguinte, igualmente passíveis de uma outra sanção que a do suplício. E individual, visto que ela é produzida caso a caso por esses procedimentos de "observação minuciosa do detalhe" (FOUCAULT, 1999, p. 121) que são os mecanismos de educação dos corpos. Por tais mecanismos passa a fabricação do indivíduo pelo poder-saber, segundo a penetrante expressão de Vigiar e punir: "a bela totalidade do indivíduo não é amputada, reprimida, alterada por nossa ordem social, mas o indivíduo é aí cuidadosamente fabricado, segundo uma táctica das forças e dos corpos" (FOUCAULT, 1999, p. 179).

Sabemos que, na relação entre o sujeito e a política, Foucault não segue os modelos clássicos. Aristóteles associa o cidadão ao governo e pergunta de que modo a virtude do primeiro deve se acordar com o exercício do segundo (ARISTÓTELES, Pol., III, 1-4). Por seu turno, os contratualistas aliam os sujeitos ao soberano e investigam os princípios racionais da transmissão do poder de aqueles a este. Em ambos os casos o pensamento político é dominado pela existência de dois elementos diretamente associados numa relação vertical. Pensemos agora no marxismo, segundo o qual a história é o terreno da luta de classes. As classes, diria Foucault, são também concebidas na vertical, como grupo minoritário e dominante dos proprietários, em cima, e grupo maioritário e dominado dos expropriados, em baixo. Em jogo nesta luta está o controlo do poder de estado, entendido como lugar da manutenção ou da mudança da estrutura de propriedade, de tal modo que a conjunção imediata que se encontrava já em Aristóteles e nos contratualistas se mantém no marxismo, ainda que transformada. A primeira originalidade de Foucault será a de estruturar o poder de uma outra forma, introduzindo, entre governantes e governados, entre soberano e sujeitos, entre dominantes e dominados, uma região nova e complexa a que chama de tecnologia política dos corpos, que desfaz o laço imediato entre os dois elementos tradicionalmente constitutivos da política.

Uma segunda originalidade diz respeito ao destino que reserva a cada um destes elementos tradicionais. Uma passagem importante para o compreendermos é a seguinte, que lemos em Vigiar e punir: "pode haver um 'saber' do corpo que não é exatamente a ciência de seu funcionamento, e um controle de suas forças que é mais que a capacidade de vencê-las: esse saber e esse controle constituem o que se poderia chamar a tecnologia política do corpo. [...] Seria impossível localizá-la, quer num tipo definido de instituição, quer num aparelho do estado. Estes recorrem a ela; utilizam-na, valorizam-na ou impõem alguns de seus procedimentos. Mas ela mesma, em seus mecanismos e efeitos, se situa num nível completamente diferente. Trata-se, de alguma maneira, de uma microfísica do poder posta em jogo pelos aparelhos e instituições, mas cujo campo de validade se coloca, de algum modo, entre esses grandes funcionamentos e os próprios corpos com sua materialidade e suas forças" (FOUCAULT, 1999, p. 26). Estas linhas nos ensinam duas coisas sobre a tecnologia política dos corpos.

Primeiro, do que ela se compõe. Ela não é nem uma ciência objetiva e abstrata, condensada em leis e princípios formais, nem uma forma nua de dominação pela violência, que reduziria os indivíduos à escravatura; ela é simultaneamente um conhecimento empírico, que se mantém assim junto da experiência; e uma maneira de impor subtilmente a ordem, por via de intervenções discretas no terreno prático. Enquanto tecnologia, ela é um saber de certas técnicas, o que faz com que nela as dimensões teóricas e práticas se encontrem estreitamente associadas. E, enquanto política, ela cruza ao mesmo tempo os domínios do poder e do saber que assim se associam. O objetivo de quem se serve dela é o de moldar os corpos para dispô-los à produção e à reprodução: "Este investimento político do corpo está ligado, segundo relações complexas e recíprocas, à sua utilização econômica" (FOUCAULT, 1999, p. 25). De tal modo que, nas relações de poder, o laço entre a tecnologia política do corpo e a disposição dos indivíduos se torna evidente: esta tecnologia deve ser entendida como indutora de disposições para agir ou padecer de certa forma, ou seja, como meio de obter uma capacidade geral, fabricando individualidades semelhantes. Numa palavra, ela é utilizada para normalizar. 
Segundo, a passagem citada nos diz algo sobre o lugar onde se encontra a tecnologia. Ela não está ao lado do estado e das instituições; ela "se situa num nível completamente diferente". Que nível é este? Trata-se por um lado de um nível intermédio, porquanto a tecnologia se encontra entre as instituições que se servem dela e os corpos que se trata de dominar. Por outro lado, ela aparece quase como fundamental, e além de permitir as relações entre as instituições e os corpos, torna possível que cada elemento se defina na relação como instituição ou corpo. Assim, a tecnologia aparece primeiro como intermédia, para logo depois ser colocada no fundo. Em outras palavras, a mediação torna-se fundadora. E a região que assegurava a comunicação entre os dois níveis tradicionais do poder se metamorfoseia em plano decisivo. Noutro texto da mesma época, Foucault apresenta este deslocamento teórico da maneira seguinte: "Dever-se-ia tentar estudar o poder não a partir dos termos primitivos da relação, mas a partir da própria relação na medida em que ela é que determina os elementos sobre os quais incide [... ]" (FOUCAULT, 2005, p. 319). Assim, o plano que parecia ser apenas intermédio se revela, no fim de contas, como determinante dos entes de poder, o que significa que os corpos são determinados pela relação da qual são um elemento, ou seja, enquanto determinados, eles não são uma realidade preexistente sob uma forma que seria natural ou essencial: a "essência" dos corpos, se é que podemos utilizar esta palavra, só é determinada adentro da tecnologia política que os forma.

Havendo estabelecido estes pontos, vejamos agora como a sombra de Artaud é afastada de Vigiar e punir, para o que voltaremos brevemente ao papel do corpo em três modelos distintos do exercício de poder, tal como Foucault os descreve - o modelo da exclusão (da lepra), o da quadriculamento (da cidade afetada pela peste) e o do panóptico. Na História da loucura, Foucault tinha recordado que entre leprosos e pessoas sãs houvera, no passado, uma partilha simples, isto é imediata e sem resto. Trata-se de uma operação que cria condições para que uma sociedade desenvolva um olhar sobre si mesma, decorrente da exclusão de uns e da conservação de outros, esquema que, de acordo com Foucault, se manterá posteriormente, mutatis mutandis, na partilha entre a loucura e a razão. Trata-se também de uma separação massiva de dois grupos. Em contrapartida, Vigiar e punir compara do seguinte modo o tratamento dado à cidade empestada: "Se é verdade que a lepra suscitou rituais de exclusão que deram até um certo ponto o modelo e como que a forma geral do grande Fechamento, já a peste suscitou esquemas disciplinares" (FOUCAULT, 1999, p. 164). ${ }^{3}$ Para compreender o que são estes esquemas, é importante reler o capítulo de Vigiar e punir intitulado "O panoptismo", bem como a descrição aí apresentada das "medidas que se faziam necessárias, segundo um regulamento do fim do século XVII, quando se declarava a peste numa cidade." O quadriculamento da cidade despoleta então uma "inspeção [que] funciona constantemente. O olhar está alerta em toda parte". De quem são estes olhos indiscretos e a quê eles prestam atenção? A cidade se encontra partilhada em dois grupos, o dos vigilantes ("os intendentes, os síndicos, os soldados da guarda"), que circulam e permanecem atentos, e o dos vigiados, basicamente todos os outros habitantes, fechados em casa, doentes ou não. $\mathrm{O}$ método mais simples para conhecer o estado de saúde de cada um consiste em chamar um a um cada ocupante, casa a casa: "Cada um trancado em sua gaiola, cada um à sua janela, respondendo a seu nome e se mostrando quando é perguntado, é a grande revista dos mortos e dos vivos." Para que esta fiscalização dê certo, é preciso que os corpos se mostrem e que os indivíduos venham à janela, tornando-se visíveis de acordo com as instruções recebidas de fora, encontrando-se frente a frente com os personagens investidos de poder pela administração. Presente por toda a cidade, o poder exige que os moradores, de quarentena, compareçam diante dele de acordo com as regras que ele estabelece. Finalmente, para que estes procedimentos funcionem, um "sistema de registro permanente é indispensável: relatórios dos síndicos aos intendentes, dos intendentes aos almotacés ou ao prefeito." No topo da escala encontramos o prefeito; no outro extremo, cada morador do qual se registraram "o nome, a idade, o sexo, sem exceção de condição". Captados desta forma pelo funcionamento administrativo, os moradores em suas casas são transformados em indivíduos, corpos cuja identidade pode ser reconhecida oficialmente. Vemos assim a diferença entre o afastamento massivo dos leprosos ou dos loucos e o tratamento individualizante dos pestilentos, que 
fixa tanto as identidades quanto o lugar que corresponde a cada uma delas. Contra o esquema milenar da exclusão da lepra, o século XVII introduz uma novidade essencial, a diferenciação oficial dos indivíduos, que simultaneamente os igualiza, posto que os reduz sem exceção a um nome, uma idade e um sexo. Temos aqui o ponto de partida de um trabalho realizado sobre todos e cada um e por isso ao mesmo tempo universal e individualizante. $\mathrm{O}$ estudo do panóptico em Vigiar e punir nos permite circunscrever um terceiro modelo de exercício do poder sobre o corpo, distinto dos que acabamos de ver. O panóptico está para o final do século XVIII como o quadriculamento está para os meados do século XVII: ele representa o esquema depurado do ordenamento dos corpos como meio para governá-los. Como sabemos, o panóptico é uma construção circular dentro da qual um anel periférico é dividido em celas. Cada cela tem "duas janelas, uma para o interior, correspondendo às janelas da torre" de vigilância que se encontra no centro do edifício; "outra, que dá para o exterior, permite que a luz atravesse a cela de lado a lado." Para quem se encontra dentro da cela, é impossível permanecer na sombra. Somente, esta possibilidade não decorre de uma instrução momentânea dada pelo poder, como quando cada morador da cidade era instado a vir à janela; ela é o estado permanente de quem quer que esteja enclausurado. A cela não é mais um lugar cujo interior escapa à vista dos de fora; ela é um espaço iluminado, idealmente transparente. O indivíduo não se mostra; ele é simplesmente visto. Daí o que Foucault chama de "efeito mais importante do Panóptico: induzir no detento um estado consciente e permanente de visibilidade que assegura o funcionamento automático do poder." A passagem do corpóreo ao incorpóreo ou do corpo à alma se torna manifesto. Como cada vigiado é plena e constantemente visível, resta a lhe fazer crer que ele é efetivamente visto ou então que pode sempre sê-lo. Esta é a função da torre de vigilância no centro do imóvel, disposta de maneira que o vigia que aí se encontre possa observar a todo o momento cada sujeito isolado, sem que nenhum destes sujeitos possa por sua vez localizá-lo. Decorre daí um efeito psicológico permanente que visa restringir as ações dos vigiados, não pela força física, mas pelo poder da consciência. Aí é produzida a "alma”. E se Foucault escreve a palavra entre aspas, é para bem sublinhar que esta "alma" mais não é do que o resultado de uma tecnologia material, de uma microfísica: “a alma, prisão do corpo” (FOUCAULT, 1999, p. 29). Podemos resumir os três modelos de relação de visibilidade da seguinte maneira. Na exclusão, os corpos do leproso e do louco se tornem invisíveis desde que são postos de lado; eles integram assim uma massa indiferenciada. De forma completamente diferente, na repartição da cidade existe uma dupla visibilidade: intermitente do lado do morador, permanente do lado do soberano. Finalmente, no panóptico o indivíduo vigiado é invariavelmente visível, ao passo que o olhar que vigia permanece disfarçado. Todos estes modelos são pontos de apoio para a crítica foucaultiana do funcionamento do poder, para o que se serve por vezes da ideia das tecnologias políticas do corpo.

Porém, o importante é frisar aqui o quanto Foucault se afastou de suas referências literárias tão presentes na primeira metade dos anos 1960, para elaborar esta crítica a meados da década de 70 . Neste âmbito, o exemplo de Artaud é eloquente. Em O Teatro e o seu duplo, Artaud introduzia o palco e a peste como quadros por excelência do afundamento e da substituição, nem que fosse momentânea, das convenções. Ora, na nova perspectiva política foucaultiana, esta concepção não tem mais valor. Como escreve Foucault, nos projetos do poder "à peste responde a ordem; esta tem como função desfazer todas as confusões: a da doença que se transmite quando os corpos se misturam; a do mal que se multiplica quando o medo e a morte desfazem as proibições. [...] Contra a peste que é mistura, a disciplina faz valer seu poder que é de análise. Houve em torno da peste uma ficção literária da festa: as leis suspensas, os interditos levantados, o frenesi do tempo que passa, os corpos se misturando sem respeito, os indivíduos que se desmascaram, que abandonam sua identidade estatutária e a figura sob a qual eram reconhecidos, deixando aparecer uma verdade totalmente diversa. Mas houve também um sonho político da peste, que era exatamente o contrário: não a festa coletiva, mas as divisões estritas; não as leis transgredidas, mas a penetração do regulamento até nos mais finos detalhes da existência e por meio de uma hierarquia completa que garante 
o funcionamento capilar do poder; não as máscaras que se colocam e se retiram, mas a determinação a cada um de seu "verdadeiro" nome, de seu "verdadeiro" lugar, de seu "verdadeiro" corpo e da "verdadeira" doença" (FOUCAULT, 1999, p. 163-164). Estamos aqui em um novo quadro, que não é mais epistemológico e literário, mas político, e nele os corpos são vistos de outra forma. ${ }^{5}$

Diferentemente de Foucault, é para pensar o poder e, mais exatamente para o contrariar, que Deleuze et Guattari seguem a inspiração de Artaud. Podemos compreendê-lo sobre três planos sucessivos - o da psiquiatria, o da exterioridade e o do juízo. Evocarei rapidamente os dois primeiros para me concentrar mais no último, que é aquele que melhor permite captar a radicalismo deleuziano. Assim sendo, o primeiro tipo de poder visado é o da psiquiatria e dos psiquiatras. Como fizera Foucault e, antes dele, o próprio Artaud, Deleuze apenas aceita a loucura ou da "doença mental" para voltá-la de imediato contra a máquina que a diagnostica. Como lemos no Anti-Édipo, "Artaud é o despedaçamento da psiquiatria, precisamente porque ele é um esquizofrênico e não porque ele não o é. Artaud é a efetuação da literatura precisamente porque ele é esquizofrênico e não porque não o é" (DELEUZE, 2010, p. 182). Mais do que consentir o diagnóstico e do que submeter-se a ele, trata-se de reivindicar a esquizofrenia. Se o Anti-Édipo começa com um apelo para a libertação do esquizofrênico, ("O passeio do esquizofrênico: eis um modelo melhor do que o neurótico deitado no divã”) (DELEUZE, 2010, p. 12), é notadamente por que reconhece a capacidade inovadora da "doença" e as faculdades libertadoras da psicose: "Como se as grandes vozes que souberam operar uma abertura da gramática e da sintaxe, e fazer de toda a linguagem um desejo, não falassem do fundo da psicose e não nos mostrassem um ponto de fuga revolucionário eminentemente psicótico" (DELEUZE, 2010, p. 181). Neste primeiro plano, Artaud serve a Deleuze e Guattari de ponto de apoio para conceber uma análise que não seja mais psíquica, mas esquizoide - uma esquizoanálise.

Um segundo nível do poder, mais geral que o da psiquiatria e que por isso mesmo o engloba, é aquele que, partindo de fora, tenta impor a cada um um corpo próprio. Neste quadro, o poder deve ser captado como: dominação produtora de subjetividade. O corpo individual é um organismo marcado por automatismos que acabam constituindo um fundo de involuntário, como uma natureza que, na verdade, lhe é "docemente" imposta. Mas ele é outrossim um objeto significante, porquanto suas escolhas e comportamentos racionais são supostos manifestar sua pertença à ordem que previamente o constituiu. Mais abstratamente ainda, o corpo é uma instância de reconhecimento de si como idêntico, logo não-esquizofrênico, como identidade dotada de sentido e de destinações. Assim, o sujeito apenas aparentemente é constituído de forma livre; na realidade, ele é estruturado a partir de fora por um Outro abstrato que exerce continuamente o seu poder. Sabemos que metáfora Deleuze e Guattari encontraram em Artaud para transformá-la em um conceito contra este tipo de produção: o corpo sem órgãos é o que opõem ao poder que faz os organismos; é o meio que encontram para perturbar, e finalmente esquivar, as dimensões tradicionalmente impostas ao corpo. Ao início no Anti-Édipo e posteriormente em Mil platôs, a organização é apresentada como assujeitamento do indivíduo ao aparelho que lhe atribui um papel determinado no funcionamento de conjunto. Visto que ela se apoia no automatismo das funções, a organização repugna a anarquia criadora que modifica o sentido dos seres; em consequência, a organização não pode ser uma condição da liberdade. Pelo contrário, ela representa a sujeição do indivíduo ao corpo geral, isto inclusive quando tudo parece sugerir o triunfo do individualismo. O corpo sem órgãos se opõe a esta produção e atribuição a cada um de um corpo estratificado; ele simboliza o esforço para inverter radicalmente o sentido e a destinação convencionais de si mesmo ${ }^{6}$.

Enfim, o terceiro nível do poder aparece sob sua forma mais límpida no capítulo intitulado "Para dar um fim ao juízo", de Crítica e clínica. O poder do juízo é o mais imaterial, o mais abstrato e também o mais generalizado, e Deleuze sugere que as formas concretas de dominação que o ocidente conheceu desde a Grécia clássica não são mais do que modalidades ou materializações dele. $\mathrm{O}$ encurtamento do título de 
Artaud, Para dar um fim ao juízo de deus, que é também um jeito de transformá-lo, se explica facilmente: por mais que se diga que Deus morreu, a estrutura teológica do juízo sobrevive sob o horizonte da infinitude, no interior do qual todo juízo se funda sobre esta estrutura, isto é na relação entre o que é julgado e o infinito dos valores para os quais o juízo apela; e posto que o juízo associa o infinito aos valores, ele continua revelando seu caráter teológico-moral (DELEUZE, 1997, p. 144). O juízo de Deus não sendo, por isso, mais que uma determinação do juízo em geral, dar-lhe um fim supõe antes de tudo que se destrua a infinitude.

Esbocemos três passos neste percurso destruidor. O primeiro passo consiste em opor, à infinitude de Deus, a finitude da crueldade. Esta palavra, como se sabe, não adquire aqui o significado que habitualmente se lhe atribui, a do prazer sentido em fazer sofrer ou em ver sofrer. Como escreve Artaud: "filosoficamente falando, o que é a crueldade? Do ponto de vista do espírito, a crueldade significa rigor, aplicação e decisão implacáveis, determinação irreversível, absoluta. [...] Atribui-se erroneamente à palavra crueldade um sentido de rigor sangrento, de busca gratuita e desinteressada do mal físico" (ARTAUD, 2006, p. 118). Ao contrário, ela deve ser compreendida como capacidade de decidir rigorosamente no presente e à vista dos atos. Sem apelar a uma infinitude do tempo nem a uma transcendência dos valores, esta decisão é absoluta e imanente; ela soluciona o problema num presente cujo único horizonte é ele mesmo. No juízo de Deus, ao invés, toda decisão definitiva reenvia para a única instância transcendente do juízo final, pronunciado por um exterior absoluto. Por este motivo, uma solução final é constantemente adiada até um momento por vir; e a justiça feita agora permanece sempre incompleta e contingente, demasiado humana. O juízo de Deus supõe a dívida infinita, a qual "só é suave na aparência, pois nos condena a uma escravidão sem fim e anula qualquer processo liberatório" (DELEUZE, 1997, p. 145)..$^{7}$ Ou pelo menos ela não é menos suave que o pagamento imediato da dívida, ainda que este pareça mais cruel ou rigoroso. O mesmo procedimento ocorre no juízo de conhecimento, igualmente dependente do infinito e cujo paradigma seria a lei científica formulada como universal e necessária. Como explica Deleuze: "Mesmo o juízo de conhecimento envolve um infinito do espaço, do tempo e da experiência que determina a existência dos fenômenos no espaço e no tempo ('toda vez que...')" (DELEUZE, 1997, p. 159; trad. 144). De tal sorte que todo juízo implica uma relação essencial com o infinito, manifesta não apenas na proposição enunciada, como também nas instâncias que pronunciam o veredicto. Deste ponto de vista, o tribunal, a crítica de arte e a peritagem psiquiátrica se encontram no mesmo patamar. Não surpreende, por conseguinte, que, para contrariar todo este funcionamento, o sistema deleuziano da crueldade se funde em uma finitude essencial, segundo a qual desde que uma reparação tem de ser feita; e uma decisão, tomada, a ação se desenrola no presente e se esgota nele. Como exprime Crítica e clínica, "os existentes se enfrentam e se dão reparação segundo relações finitas que não constituem senão o curso do tempo” (DELEUZE, 1997, p. 144). ${ }^{8}$

Um segundo passo na destruição do princípio de infinitude associa à crueldade a embriaguez. São conhecidas as narrativas de experiências com as drogas, desde os paraísos artificiais de Baudelaire até ao peyotl contado por Artaud. E é o próprio Baudelaire quem, a respeito dos efeitos do haxixe, insiste numa diferença crucial entre a embriaguez, seja ela provocada pelas drogas ou pelo álcool, e o sonho: é que aquela não pode ser interpretada.' Seguindo a mesma linha, Deleuze escreve que "os ritos do peyotl, segundo Artaud, [...] não são sonhos, porém estados de embriaguez ou de sono" (DELEUZE, 1997, p. 147). ${ }^{10}$ Aliás, a inspiração etnológica do conceito de crueldade é notória; aí encontramos a atração de Artaud pelos índios do México. Por exemplo, ele conecta explicitamente a finitude e a crueldade à vida das comunidades indianas da América Central, em "Tutuguri, o rito do sol negro", capítulo de Para dar um fim ao juizo de deus. Do mesmo passo, tocamos os estudos de Marcel Mauss, de Bataille e de Lévi-Strauss sobre o dom, o sacrifício, e o tipo de justiça e de relação que estes instauram entre os indivíduos. A busca dos estados de embriaguez acompanha, assim, o sistema etnológico da crueldade. 
Num terceiro momento, Deleuze retoma o corpo sem órgãos: "Criar para si um corpo sem órgãos, encontrar seu corpo sem órgãos é a maneira de escapar ao juízo.” O antiorganicismo volta com toda sua potência em Crítica e clínica: "Deus criou para nós um organismo [... ] ali onde tínhamos um corpo vital e vivente. Artaud apresenta esse 'corpo sem orgãos' que Deus nos roubou para introduzir o corpo organizado sem o qual o juízo não se poderia exercer. O corpo sem órgãos é um corpo afetivo, intensivo, anarquista, que só comporta polos, zonas, limiares e gradientes. Uma poderosa vitalidade não-orgânica o atravessa.” Mas o corpo pode ser individual ou político, corpo próprio ou corpo de outrem. A anarquia que nós oferecemos se opõe à hierarquia e à organização com que o poder exterior nos rodeia. Entre a crueldade e o juízo existe todo um problema político considerável. A tal ponto que o sistema da crueldade pode ser usado tanto individualmente quando politicamente. A comunidade que rege por um sistema assim, como certas tribos mexicanas, é um corpo sem órgãos. Mas também nas sociedades dominadas pelo juízo, a crueldade permanece ainda como uma via possível para o sujeito, como meio de escapar ao regime que lhe é imposto do exterior.

Ora, entre os planos individual e coletivo vemos estabelecer-se uma relação de luta. Tomar parte nessa luta será o quarto e último movimento para destruir o juízo: "combate, por toda a parte combate, o combate substitui o juízo. Sem dúvida, o combate aparece contra o juízo, contra suas instâncias e seus personagens.” Este tema é artaudiano por excelência, pois como escreve o poeta: “Toda minha obra só foi construída e só poderá sê-lo em cima deste nada,/ desta carnificina, desta mescla de fogos apagados, de gritos secos e chacinas, / a gente não faz nada, a gente não diz nada, mais a gente sofre, se desespera e se bate, sim, creio que na realidade a gente se bate" (ARTAUD, 1974, t. XII, p. 236). O combate perpétuo tem uma dimensão simbólica: não se decide de entrar nele, pois combater não é uma atitude escolhida e a existência do combate não depende de nós; ele é bem mais o modo de ser da vida. Neste sentido, a crueldade está para além do bem e do mal; ela é a vida na justiça e na injustiça simultâneas do combate. Mais ainda, o combate não se esgota na tensão entre combatentes, pois uma dimensão talvez mais fundamental encontra-se no interior de si mesmo, como combate consigo mesmo. Deleuze prossegue: "mais profundamente, o próprio combatente é o combate, entre suas próprias partes, entre as forças que subjugam ou são subjugadas, entre as potências que exprimem essas relações de força”. Pelo encarniçamento e a dilaceração que implica e dos quais Artaud seria um exemplo em carne viva, pode comparar-se este combate a um suplício infligido pelo indivíduo a si próprio, uma ideia aliás evidente nas operações destinadas a dar ao homem um corpo sem órgãos, tais como Artaud as descreve.

Resumindo, a originalidade da leitura deleuziana de Artaud reside em dois pontos: primeiro, na atenção que dá à luta constante para libertar-se, pela crueldade, do constrangimento exterior do poder, compreendido como organização; segundo, na radicalização da imanência reclamada por Artaud: no final da vida, o poeta reivindica nossa emancipação, já não de Deus (ou melhor: de deus, que escreve com minúscula), acerca do qual sabemos, desde Nietzsche, que está morto, mas daqueles que julgam em seu nome ou em seu lugar e que, assim, perpetuam a tradição. Deleuze dá um passo mais, para visar as estruturas cosmológicas sobre as quais se apoiam estes juízos, isto é a infinitude do tempo e a obsessão da ordem. Numa palavra, um corpo cujo funcionamento não seja mais atravessado e constituído pelo par jurídico-teológico, tal é o caminho para opor-se ao poder do afora, que a todo instante nos julga e abafa a criação. Pela mesma razão, podemos entender o que separa Foucault de Deleuze com respeito a Artaud: por um lado, o que ao início reteve a atenção de Foucault - a saber: a experiência do excesso - é o ponto de chegada de Deleuze; por outro lado, Foucault passa da experiência literária à do corpo como alvo do poder, ao passo que Deleuze associa cada vez mais estritamente a literatura, o corpo e o poder. Está claro que nos encontramos diante de vias divergentes, para não dizer opostas: assim que se interessa pelo corpo e o poder, Foucault renuncia a Artaud; quando liga os mesmos temas, Deleuze se entrega ao poeta. 
Chega então o momento de examinar, brevemente o terceiro e último dos três polos do trabalho de Foucault, típico dos anos oitenta - o polo ético. Nesse momento, já há muito que ele não trata mais de Artaud nem se inspira dele. Vimos por quê no domínio político (a desordem da peste não lhe serve para pensar o funcionamento e a lógica de pensamento do poder), mas a razão agora é outra, concernente a um outro campo da experiência humana: ela tem que ver com o caráter central da escolha pessoal. Para bem o entendermos, regressamos ao Artaud admirado pelo Foucault da História da loucura. Com certeza, o que na revolta do poeta o tocava mais profundamente nessa época era sua recusa da racionalidade que o mundo exige de nós. Por hábito, o louco é aquele cujas escolhas e atos são considerados como irrazoáveis e que seria necessário corrigir ou curar. Contudo, estas duas vias são precisamente afastadas por Artaud desde seus primeiros textos, quando se apresenta como não sendo nem corrigível nem curável, e sua "assustosa doença da mente" como sendo uma corrida inevitável em busca de si mesmo. É o que escreve já em uma de suas cartas ao diretor da Nouvelle Revue Française, Jaques Rivière, em 5 de junho de 1923: "Meu pensamento me abandona, a todos os níveis. Desde o simples fato do pensar até ao fato exterior de sua materialização nas palavras. Palavras, formas de frases, direções interiores do pensamento, reações simples do espírito, constantemente persigo o meu ser intelectual. Então, assim que posso captar uma forma, por imperfeita que seja, a fixo, receoso de perder todo pensamento" (ARTAUD, 1974, t. I, vol. 1, p. 24) A mesma ideia permanece até ao final da sua vida, como provam as seguintes linhas, redigidas vinte e três anos mais tarde, em 1946, nas quais, em uma carta a Peter Watson, retoma a impossibilidade de escolher: "Comecei em literatura escrevendo livros para dizer que não poderia escrever coisa alguma, meu pensamento quando eu tinha algo a dizer ou a escrever era o que me era mais recusado” (ARTAUD, 1974, t. I, vol. 1, p. 230). Esta carta insiste que o resto de seu trabalho é incluído no mesmo movimento: "Mas espere um pouco para pensar ter algo a dizer, Sr. Artaud./ Não, eu, Antonin Artaud, isso é que não, isso é que precisamente não, eu, Antonin Artaud, só quero escrever quando não tenho mais nada que pensar" (ARTAUD, 1974, t. I, vol. 1, p. 234). Assim, uma relação evidente se estabelece entre as capacidades de escrever, de pensar e de escolher: aqui, a escrita não tem mais a ver com o pensamento compreendido como escolha das palavras; ao invés, ela deve fixar o que puder. Se trata então de fixar o que calha e não de escolher entre coisas que teriam sido previamente pensadas. Esta ausência de escolha, que convidou Foucault a pensar a loucura, a transgressão e a criação, é dificilmente concebível no quadro ético, que implica escolhas acerca de si mesmo, do que se é, do que se quer ser e de como se pretende agir.

Deste modo, todo um novo quadro teórico ganha forma. Na ética, ao assujeitamento pelas forças e dispositivos exteriores se opõe a subjetivação tornada possível pela dobra da força sobre si mesma, como Foucault resume numa entrevista de 1984: "o sujeito se constitui através das práticas de assujeitamento, ou, de maneira mais autônoma, através das práticas de liberação, de liberdade, como na antiguidade, a partir, claro, de um certo número de regras, estilos, convenções, que se encontram no meio cultural” (FOUCAULT, 1994, p. 733). A partir daqui, duas ideias importantes merecem ser retidas. Primeiro, na leitura foucaultiana dos antigos, a liberdade de cada um não reside em seu poder de conformar-se com uma lei moral universal, mas em sua capacidade de dobrar-se sobre si para criar seus próprios valores e regras de conduta. Como lemos no Uso dos prazeres, "a exigência de austeridade implicada pela constituição desse sujeito senhor de si mesmo [... se apresenta [... ] como um princípio de estilização da conduta para aqueles que querem dar à sua existência a forma mais bela e mais realizada possível” (FOUCAULT, 1998, p. 218). Diga-se de passagem que a análise mais sugestiva da ética como dobra da força sobre si mesma foi elaborada por Deleuze em seu livro intitulado Foucault, onde escreve: "Eis o que fizeram os gregos: dobraram a força, sem que ela deixasse de ser força. Elas a relacionaram consigo mesma” (FOUCAULT, 2005, p. 108). A outra ideia que devemos reter é a seguinte: a ética não é inteiramente a região da tranquilidade nem da serenidade, e nos precipitaríamos crendo que ela representa a escolha daquele que se retira da vida em comum. Quando lemos bem, não é nada disso e Foucault exprimiu toda a sua surpresa diante daqueles que interpretam a 
vida ética como uma retirada para dentro de si. O curso $A$ Hermenêutica do sujeito resume bem este ponto: "Temos pois o paradoxo de um preceito do cuidado de si que, para nós, mais significa egoísmo ou volta sobre si e que, durante tantos séculos, foi, ao contrário, um princípio positivo, princípio positivo matricial relativamente a morais extremamente rigorosas" (FOUCAULT, 2006, p. 17). Fiel a esta tradição, Foucault vê na vida ética o lugar de uma preparação para a vida em comum, segundo a imagem, que tanto o seduzia, do atleta exercitando-se para o combate (FOUCAULT, 2006, p. 387-388).

Existe algo de paradoxal na expressão "heterotopias do corpo" quando pensamos em Foucault. ${ }^{11}$ Este é por certo um pensador das heterotopias e também dos corpos. Porém, ele dificilmente conjuga os dois termos, por tratar os corpos antes de mais como objetos ora de tecnologias políticas (de suplício, disciplina, exame) ora de técnicas da existência (concebidas de um ponto de vista ético); e as heterotopias, menos como corpóreas do que como linguísticas (como formas de ruína da ordem que se estabelece entre palavras e coisas) ou espaciais (heterotopias do jardim, do cemitério, da missão religiosa). Nesta situação, Deleuze oferece perspectivas interessantes sobre como escapar ao poder pelo corpo. São estes dois discursos, foucaultiano e deleuziano, que tentamos comparar com a ajuda de uma terceira referência, Artaud. Consegue-se assim trazer à luz uma rede de tensões, de cumplicidades, de mudanças e de distanciamentos entre Deleuze e Foucault. Julgamos muitas vezes que entre eles apenas há afinidades e que, ao fim e ao cabo, eles defendam as mesmas posições em filosofia ou, para sermos talvez mais rigorosos, em suas margens, visto Foucault se ter assumido como um historiador de novo tipo e Deleuze nunca ter escondido seu desprezo pela prática institucional da disciplina, notadamente sob a forma de uma história da tradição demasiado meticulosa. No termo da reflexão, vemos o quanto Deleuze persegue até à última o trabalho de Artaud: desafiar o juízo significa fazer o impossível para abrir brechas nos muros da organização, o que se exprime exemplarmente no tornar-se-um-corpo-sem-órgãos. Foucault, por seu lado, descobre uma ética como conversão a si com vista a um novo desdobramento que seria uma nova relação com outrem. Artaud, aqui, desaparecera já há muito tempo. ${ }^{12}$

\section{NOTAS}

1. Uma primeira versão deste texto foi apresentada, como conferência de abertura, ao IX colóquio internacional Michel Foucault, "Foucault e as heterotopias do corpo", organizado pela Universidade Federal de Pernambuco e o Instituto Ricardo Brennand de Recife, sob a direção de Durval de Albuquerque et alii, entre os dias 14 e 17 de abril de 2015.

2. Ver igualmente ARTAUD (1974, p. 14-15). Também ANDRÉ-CARRAZ (1973, p.139) e DERRIDA (2002, p. 34-35 e 44).

3. As citações seguintes são todas extraídas das primeiras páginas do capítulo III, "O Panoptismo”.

4. Todas as traduções citadas neste artigo poderão ser ligeiramente modificadas.

5. Me pergunto se não estamos autorizados a ver, na ideia da peste e da "ficção literária da festa: as leis suspensas, os interditos levantados, o frenesi do tempo que passa, os corpos se misturando sem respeito, os indivíduos que se desmascaram, que abandonam sua identidade estatutária e a figura sob a qual eram reconhecidos, deixando aparecer uma verdade totalmente diversa", um quadro que se aproxima da ruína heterotópica da ordem, tal como descrita na introdução das Palavras e as coisas (FOUCAULT, 1999a). Vejamos em todo o caso o quanto o desejo de ordem absoluta é aparentado à utopia: assim, como "a cidade pestilenta, atravessada inteira pela hierarquia, pela vigilância, pelo olhar, pela documentação, a cidade imobilizada no funcionamento de um poder extensivo que age de maneira diversa sobre todos os corpos individuais - é a utopia da cidade perfeitamente governada." (FOUCAULT, 1999b, p. 200, trad. p. 164.) 
E quando Foucault fala do panóptico, lembra que "muitas vezes se fez dele uma utopia do encarceramento perfeito. [...] O fato de ele ter, até nosso tempo, dado lugar a tantas variações projetadas ou realizadas, mostra qual foi durante quase dois séculos sua intensidade imaginária." (Idem, p. 207; trad., p. 170.) Deste ponto de vista, os dois modelos são outros tantos retratos de arranjos plenamente sucedidos, com vista a um ordenamento rigoroso. A conotação depreciativa associada ao uso do termo "utopia" neste texto não deve surpreender-nos, pois sabemos, pelo menos desde As Palavras e as coisas, que Foucault não perde uma ocasião de descreditar as utopias.

6. Sobre a destruição do sentido convencional das coisas, ver "La mise en scène et la métaphysique" [1931], Le théâtre et son double, in ARTAUD (1974, t. IV, p. 52). Sobre o corpo sem órgãos enquanto radicalização desta destruição, ver “Conclusion”, Pour en finir avec le jugement de dieu [1948], in ARTAUD (1974, t. XIII, p. 104).

7. Sobre a dívida infinita e a doutrina do juízo, Deleuze reenvia a Nietzsche, Genealogia da moral, II e ao $\$ 42$ do Anticristo.

8. Ver também o caso do chefe etíope, que submete à escravidão os príncipes vencidos, in ARTAUD (2006a, p. 121; trad., p. 118).

9. Ver Baudelaire, "Le théâtre de Séraphin”, Les Paradis artificiels [1860] e Le Théâtre de Séraphin, in ARTAUD (1974, t. IV, p. 178). Este texto, que deveria ter sido publicado em $1938 \mathrm{em} \mathrm{O}$ Teatro e o seu duplo, acabou sendo dado ao prelo em 1948. Ver ARTAUD (1974, t. IV, p. 388, n. 1).

10. As citações seguintes são extraídas das p. 164-165; trad., p. 148-149 (DELEUZE, 1997).

11. Recordo que este artigo foi inicialmente preparado para o colóquio "Foucault e as heterotopias do corpo".

12. Este artigo foi escrito com o apoio financeiro da Fundação para a Ciência e a Tecnologia - FCT (Portugal) no âmbito do programa Formação Avançada de Recursos Humanos - FARH. Durante o debate que se seguiu à apresentação em Recife, André Macedo Duarte e Vera Portocarrero introduziram dois pontos que convém mencionar. Primeiro, existe uma dimensão vitalista na escrita de Deleuze, com impacte evidente em seu discurso acerca do corpo, ao passo que a vibração vitalista é menos intensa em Foucault. Segundo, explorar o tema da vida num e noutro autores implicaria retormar a referência a Canguilhem e não pensar em termos de binômios (corpo/alma, corpo/mente), mas em termos de singularidades heterotópicas e criadoras, e de acontecimentos e incorporais.

\section{REFERÊNCIAS}

ANDRÉ-CARRAZ, D. 1973. L'expérience intérieur d'Antonin Artaud. Paris, Le cherche midi éditeur/Éditions Saint-Germain-des-Prés, $3^{\text {a }}$ ed.

ARISTÓTELES. 1985. Política. Brasília: UNB.

ARTAUD, A. 1974. Euvres complètes. Paris: Gallimard.

.2006a. Cartas sobre a crueldade. Primeira carta. Trad. Teixeira Coelho. São Paulo: Martins Fontes. .2006b. O Teatro e seu duplo. Trad. Teixeira Coelho. São Paulo, Martins Fontes.

DELEUZE, G. \& GUATTARI, F. 2010. O Anti-Édipo: capitalismo e esquizofrenia 1.Trad. Luiz B. L. Orlandi. São Paulo: 34. (L'Anti-OEdipe: Capitalisme et schizophrénie, I, Paris, Minuit).

DELEUZE, G. 1997. Crítica e clínica. Trad. Peter Pál Pelbart. São Paulo, Editora 34, col. “Trans”. (Critique et clinique. Paris, Minuit, 1993). 

1986).

2005. Foucault. Trad. Claudia Sant'Anna Martins. São Paulo, Brasiliense. (Foucault. Paris, Minuit,

DERRIDA, J. 2002. Artaud le Moma. Paris: Galilée, col. "Écritures/Figures", p. 34-35 e 44.

FOUCAULT, M. 1961. Histoire de la folie. Paris: Gallimard, “Tel”, 1996.

. 1966. “La pensée du dehors”. In: Dits et écrits, n 38, t. I, p. 522.

. 1994. “La folie et la société”. In: Dits et écrits, t. II, Paris, Gallimard, 1970.

. 1994. “Une esthétique de l'existence”. In: Dits et écrits, n 357, t. IV, Paris, Gallimard, 1984.

. 1998. O Uso dos Prazeres. $8^{a}$ ed. Trad. Maria Thereza da Costa Albuquerque. Rio de Janeiro,

Graal (L’Usage des plaisirs, Paris Gallimard, 1984).

.1999. As Palavras e as coisas. $8^{\mathrm{a}}$ ed .Trad. Salma Tannus Muchail. São Paulo: Martins Fontes. (Les Mots et les choses. Paris, Gallimard, 1966).

.1999. Vigiar e punir: nascimento da prisão. 20a edição. Trad. Raquel Ramalhete. Petrópolis, Vozes.

(Surveiller et punir: Paris, Gallimard, 1975).

.2005. Em Defesa da Sociedade. Trad. Maria Ermantina Galvão. São Paulo: Martins Fontes. (Il faut défendre la société, Paris, Le Seuil, 1997).

.2006. A hermenêutica do sujeito. Trad. Marcio Alves da Fonseca e Salma Tannus Muchail. São Paulo, Martins Fontes.

NIETZSCHE, F. 1886. Jenseits von Gut und Böse. Vorspiel einer Philosophie der Zukunft. Leipzig: Naumann.

TERNES, J. 2011. Foucault, do retorno da linguagem ao dizer-verdadeiro. Aurora, Curitiba, vol. 23, n. ${ }^{\circ}$ 32, p. 131-144, jan./jun. 